\title{
BODY IMAGE, SELF-ESTEEM AND QUALITY OF SEXUAL LIFE AMONG WOMEN AFTER HYSTERECTOMY
}

\section{Naglaa Sobhy Abd el Gwad', Amal Sobhy Mahmoud², Sonia Mohamed El-Sayad², Basel Abd El Fatah ${ }^{4}$}

M.Sc Psychiatric Nursing and Mental Health Department, Faculty of Nursing, Port Said University ${ }^{1}$, Professor of Psychiatric Nursing and Mental Health Department, Faculty of Nursing, Port Said University ${ }^{2}$, Assistant Professor Psychiatric Nursing and Mental Health Department, Faculty of Nursing, Port Said University ${ }^{3,}$ lecturer of Surgical Oncology Department, Faculty of Medicine, Mansoura University ${ }^{4}$

\begin{abstract}
Background: Hysterectomy is particular type of surgery, which can influence the patient's life. In fact, deciding to undergo hysterectomy is a difficult process for every woman, especially psychologically. Aim: This study aims to investigate the relation between body image, self-esteem and quality of sexual life among women after hysterectomy. Subjects and Method: A descriptive correlational research design was used. The study was conducted at outpatient clinic of Oncology Center of Mansoura University. The study involved 188 women with hysterectomy. Tools of data collection: used four tools; body image scale, selfesteem scale, Quality of sexual life questionnaire and an interview_questionnaire. The data was collected through an interview questionnaire. Results: Revealed that above half of women_with hysterectomy was high concern with body image, majority of women with hysterectomy had high level of self-esteem and above three quarters of women reported being satisfied with their sexual life after hysterectomy. Conclusion: There was a strong positive correlation between patient's body image and self-esteem also, positive correlation between patient's self-esteem and quality of their sexual life. The main recommendation: Suggested is_initiating comprehensive health educational programs as well as rehabilitation programs for all women following cancer treatment in outpatient's clinics of oncology department units should be held, including psychological, social and physical related- issues.
\end{abstract}

Key words: body image, hysterectomy, quality of sexual life, self-esteem 


\section{INTRODUCTION}

Hysterectomy, is the surgical removal of the uterus, is one of the most common surgical procedures in gynecology worldwide. It is most commonly performed because of benign disease, such as fibroids, bleeding disorders, endometriosis, and uterine prolapse (Hammer et al 2015).

Hysterectomy is a particular type of surgery, which can influence the patients' future life. In fact, deciding to undergo hysterectomy is a difficult process for every woman, especially psychologically. Uterus is the symbol of femininity, sexuality, fertility, and maternity, and the loss of this organ is identified as the loss of womanhood (Solbraekke \& Bondevik, 2015; Yen et al., 2008). Following the surgery, women may also battle feelings of hopelessness and despair, which may affect their psychosocial state. Having a hysterectomy can have a huge impact on a woman's life and relationships, as well as her perceived role in society. In addition to those psychosocial drawbacks, women in this population also experience physical complications. One major complication of hysterectomy is edema and swelling in both legs. In addition, complications such as numbness, tingling, and limited physical movement of the legs can remain long after surgery (Pinar, et-al 2012).

Body image reflects a direct personal perception and self-appraisal of one's physical appearance, whereby negative thoughts and feelings related to one's body indicate a disturbance of body image and lead to dissatisfaction with one's self. A high personal investment in one's body image can act as a source of self-worth (Afshari, et-al, 2016). Scarring following hysterectomy can be interpreted as a form of mutilation and may result in impaired body image (Flory, et-al,2005).

Self-esteem is considered as positive or negative attitude toward one's self, and includes feelings of self-satisfaction (Bayram \& Şahin, 2008). Generally, an early menopause and the thought of removing a healthy organ cause negative points of view. Thoughts like being scared of growing old, body image changes, and the sense of reduction in feminine properties after hysterectomy causes a self-esteem reduction, Also may cause a sense of emptiness and a loss of creativity (Gün \& Kömürcü, 2013; Azadeh , 2002).

On the other hand, sexual functioning following hysterectomy is a major concern of patients. Unfortunately, the hysterectomy impact on sexual function is unclear and the estimated women sexual dysfunction prevalence after hysterectomy differs widely mainly 
due to methodological differences. Certainly, hysterectomy outcomes depend on many factors and this also explains variations in post-hysterectomy sexual dysfunction incidence (Illiano, , 2016). Hormonal and anatomical changes that take place with hysterectomy may explain sexual dysfunctions occurrence. Rates of post-hysterectomy sexual dysfunction in women are estimated to be $2-11 \%$ for low orgasm, 5-11\% for decreased sexual desire, $2-$ $7 \%$ for dyspareunia and 9-21\% for vaginal dryness (Illiano, , 2016; Roovers,2003).

Accordingly, medical teams in particular nurses must be aware of these potential complications that accompanied hysterectomy and use the suitable nursing interventions to overcome these problems (Pinar et al, 2012).

\section{Significance of the study:}

The uterus has been considered an organ adjusting and controlling the important physiological functions, pregnancy, childbirth, sexual organ, source of energy, and an organ maintaining the attractiveness and beauty of women. Moreover, it comprises an important part of women's self-image, and loss of uterus means the loss of sense of femininity (Danesh et al , 2015). The impact of hysterectomy on sexual function has always been a great concern to women and is a major source of preoperative anxiety (Briedite et al, 2014). Hysterectomy and mastectomy operations deeply influence the perception of women's sexuality, body image and femininity (Keskin \& Gumus, 2011). Therefore, it is the intent of this study to highlight the impact of going through hysterectomy on body image, self-esteem and quality of sexual life among women.

\section{AIM OF STUDY}

This study aims to investigate ate the relation between body image, self-esteem and quality of sexual life among women after hysterectomy.

Objectives:

- Assess body image among women after hysterectomy.

- Determine levels of self-esteem among women after hysterectomy.

- Identify quality of sexual life among women after hysterectomy.

- Reflect the relationship between body image, self-esteem, quality of sexual life among women after hysterectomy. 


\section{SUBJECTS AND METHOD}

\section{Study Design:}

A descriptive correlational research design was used for the current study.

Setting: The present study was carried out at the outpatient clinic of Oncology Center of Mansoura University. Its main objective is to provide comprehensive management of all types of tumors and blood diseases for all citizens in Dakahlia and Delta Governorates. It consists of 13 floors which contain departments for inpatient.

Subjects: The study subjects comprised of a convenience woman with total number of 188 women who were coming for follow up in out-patient clinic after hysterectomy in the previously mentioned center.

\section{Sample Size:}

The sample size was determined by using the following equation was used (Dobson, 1984):

$\mathrm{Z} 2$

Sample size $(n)=----------\quad P(100-P)$

$\Delta^{2}$

Where:

n: $\quad$ Sample size

P: $\quad$ Prevalence of women all over the world will have hysterectomy $=40 \%$ (Reproductive Health Matters).

$\mathbf{Z}_{\alpha / 2}$ : A percentile of standard normal distribution determined by $95 \%$ confidence level $=$ 1.96

$\Delta^{2}: \quad$ The width of the confidence interval $=7$.

The total sample size is 188 women.

\section{Tools of Data Collection:}

1-Body Image Scale: Which developed by Hopwood et-al., (2011) and translated to Arabic language by Gamal, (2015) which contain affective (e.g. feeling self-conscious), behavioral (e.g., difficulty looking at the naked body) and cognitive (e.g., satisfaction with appearance). It includes 10 items scored on four-point Likert scale ranging from (not at all) to (very much). A total score ranging between 0 and 30 degrees. Women with score 0 to10 have minimum concerns of their body image, while women with score 11 to 20 have moderate concern of their body image. While women with score 21-30 have high concern of body image. The original scoring system uses four point Likert rating scale ranging from (0)Not at all, (1) A little, (2)Quite a bit, (3)Very much with a total score ranging between 0and 
30degrees as zero represent: "No symptoms or distress' and higher scores corresponding to 'increasing distress and concern of body image ".the Reliability of the Arabic version of the tool was held on 20 post hysterectomy women. Test -retest-reliability coefficient was held on the same patients 10 items was (0.94) which indicate that the Arabic version of demonstrated excellent scale reliability

2- Self Esteem Scale: This tool was developed by Rosenberg (1965) and translated to Arabic language by Gamal (2015). It is a ten ranking items scale concerned with measuring the impact of surgery on general feelings of the patients about themselves as self-respect, self-worth, satisfaction and their qualities. Scoring system used 4 point Likert rating scale, ranging from 0(Strongly disagree), 1 (Disagree), (Agree) and (3) Strongly agree .A total score ranging between 0 , and 30 degrees. Score below 15 suggests low self-esteem. Between 15 and 25 are within normal range, while score above 25 suggests high selfesteem. Reliability of the tool was held on the same 20 pilot post hysterectomy women. Test-retest-reliability coefficient was held on the same patients by the same investigator within 14 days interval in the same setting. Its value for 10 items was ( $r=0.9)$.

3- Quality of Sexual Life Questionnaire: This tool was developed in Arabic language by Gamal, (2015). The tool is composed of 20 items, and measures two dimensions of quality of sexual life; sexual satisfaction and sexual wellbeing. A four point Likert rating scale format was used to score the 20 item, as follows: (1) strongly dissatisfied, (2) dissatisfied, (3) satisfied, (4) strongly satisfied. Total scores range from 20 to 80 . From 0-to 40 means satisfied from their sexual life, and from 41 to 80 means dissatisfied from their sexual life. In addition,

4- Interview Questionnaire which was developed by the researcher after review of literature. It included personal data items as patient's age, residence, and duration of marriage. While, the clinical data questionnaire included date of hysterectomy, psychological and sexual complains and data concerning chemotherapy or radiotherapy.

Pilot Study: was carried out on a total of $10 \%$ of the sample (20 of post hysterectomy women) according to the criteria of selection at Oncology Center of Mansoura University before starting the data collection to test the clarity and applicability of the tools and it served to estimate the proper time required for answering the questionnaire. 
Field Work: The director of Oncology Center of Mansoura University were informed about the purpose of the study once permission were granted to proceed in this proposed study 188 post hysterectomy women who fulfilled the inclusion criteria were approached by the researcher to gain their approval to participated in the study then researcher started data collection by introducing herself to participants, explain to them the purpose of study and assure confidentiality. Oral consent was obtained from each selected patient for participation in the study after explaining the aim of the study.

Ethical Consideration: was obtained from the director of the oncology center of Mansoura University up on a letter issued from the faculty of nursing including the aim of the study. All participants in the study and health care providers were informed about the purpose and benefits of the study and were informed that the investigator is a master candidate at the faculty of nursing, Port Said University.

\section{Statistical Design:}

Data entry and statistical analysis were done using SPSS 16.0 statistical software package. Data were presented using descriptive statistics in the form of frequencies and percentages for qualitative variables and means and standard deviations for quantitative variables. Qualitative categorical variables were compared using chi-square test. Whenever the expected values in one or more of the cells in a $2 \times 2$ tables was less than 5, Fisher exact test was used instead. In larger than $2 \times 2$ cross-tables, no test could be applied whenever the expected value in $10 \%$ or more of the cells was less than 5. Pearson correlation coefficient was used to study the correlation among quantitative variables. Statistical significance was considered at $\mathrm{p}$-value $<0.05$.

\section{RESULTS:}

The present study revealed that $61.2 \%$ of participated women their age ranged between 55 to 65 years old while only $3.2 \%$ of women were between 25 to 35 years old. Also, it was found that about one third of participants were illiterate $(32.4 \%)$, one quarter graduated had secondary education $(25.6 \%)$ and $18.6 \%$ can read and write. Furthermore, regarding the employment status, the majority of women $(84.0 \%)$ were housewives and $60.1 \%$ were living in rural areas. All participants didn't have any sexual disease except only $0.5 \%$ who were suffered from veganism's. Also, about one quarter of participated women were suffered from some medical illness like diabetes mellitus, cardiac diseases and blood pressure diseases $(25.5 \%)$, 
and only $0.5 \%$ had psychological problem (depression). Moreover, $22.9 \%$ of participants had undergone other surgical operations such as cholecystectomy, appendectomy and eye surgeries, in addition to only $0.5 \%$ had undergone open heart surgery. Furthermore, $60.1 \%$ of women were received chemotherapy and $14.4 \%$ undergoing radiation treatment after hysterectomy.

Figure (1): shows that $72.9 \%$ of women were highly concerned with their body image, while $19.7 \%$ were moderately concerned and finally only $6.4 \%$ were concerned with their body image in low level.

Figure (2): It was found that from $70.2 \%$ of women had high level of self-esteem, while 29.3\%have moderate level.

Figure (3): illustrates level of satisfaction about sexual life among the women. It was found that $89.6 \%$ of the women reported being satisfied with their sexual life after under-going hysterectomy.

Table (1): shows, it was found that a strong positive correlation between the women's body image perceptions and their self-esteem $(\mathrm{r}=0.23, \mathrm{P}=0.001)$ as well as their quality of sexual life $(\mathrm{r}=0.22, \mathrm{P}=0.002)$. Also, there was a positive correlation between the women's selfesteem and quality of their sexual life $(r=0.19, \mathrm{P}=0.00)$.

All women's didn't have any sexual disease except only $0.5 \%$ who was suffered from veganism's vaginismus.

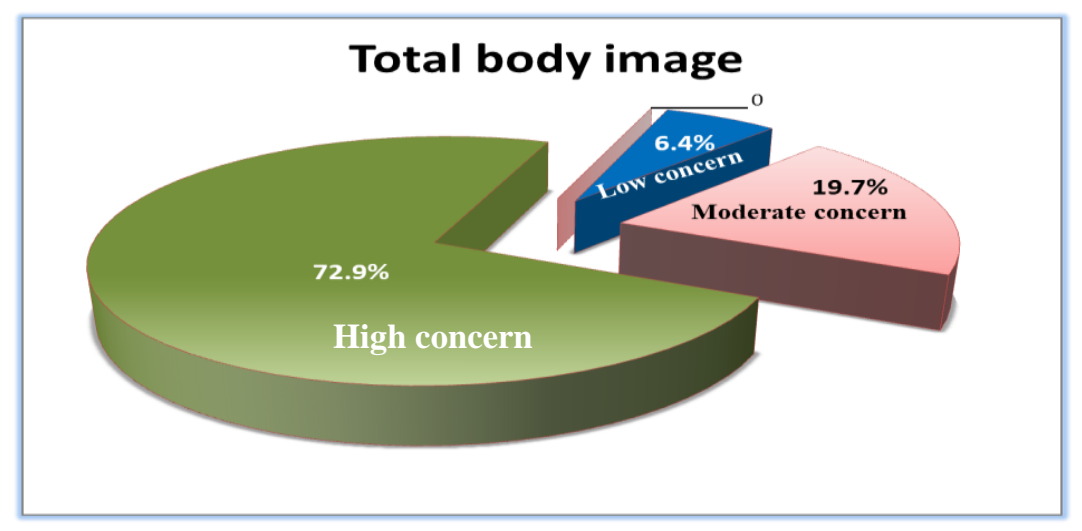

Figure (1): Levels of concerns of body image among women $(\mathrm{N}=188)$. 


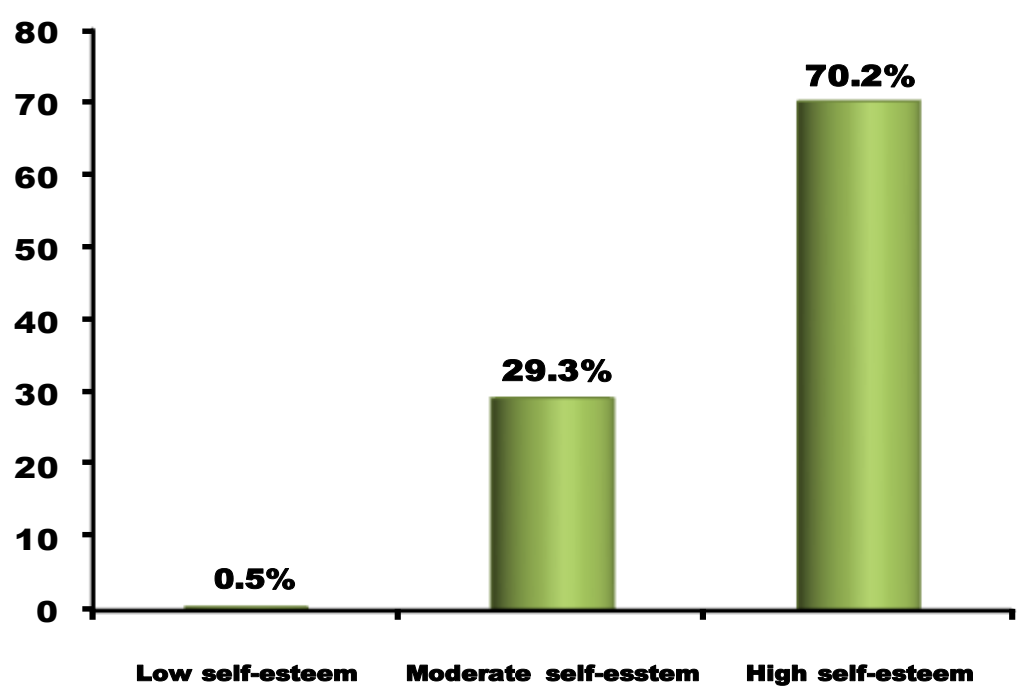

Figure (2): Levels of self-esteem among women ( $\mathrm{N}=188)$

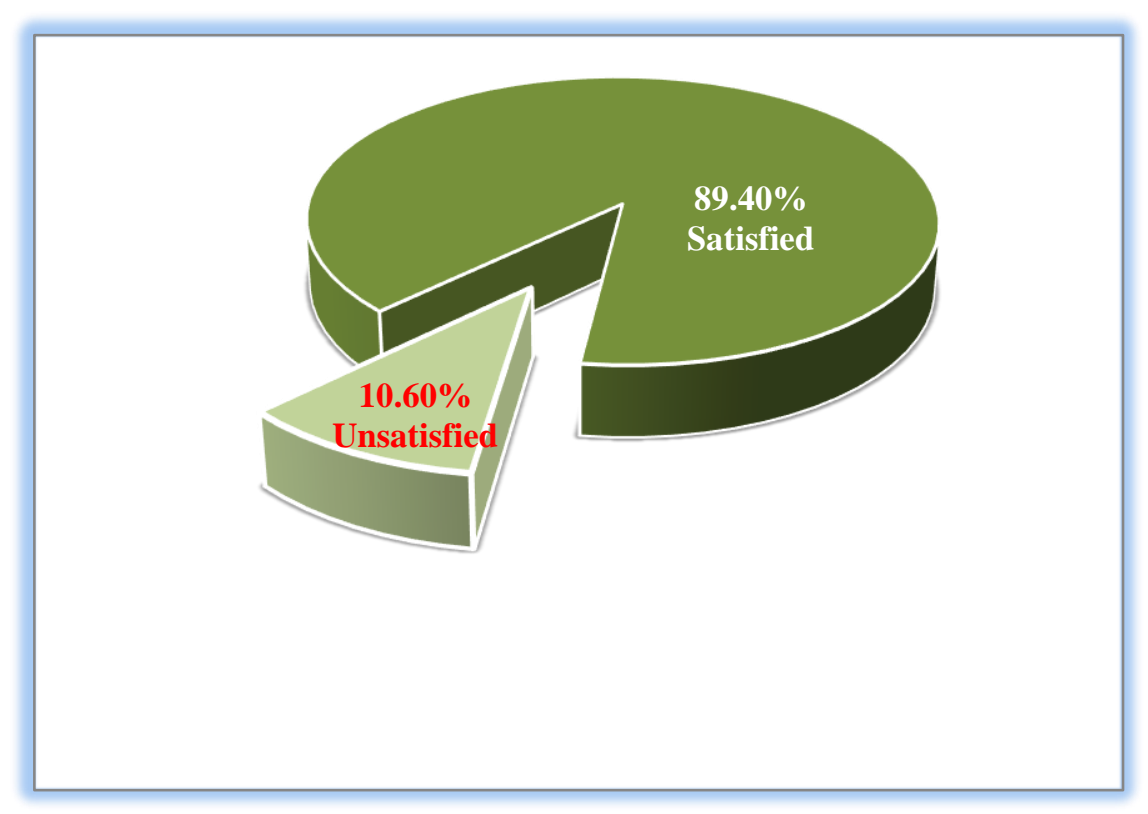

Figure (3): level of satisfaction about sexual life among studied women (N=188). 
Table (1): Correlation between women body image, self-esteem and quality of sexual life

\begin{tabular}{|l|l|l|l|}
\hline \multirow{2}{*}{ ITEMS } & Body image & Self-esteem & Quality of sexual life \\
\hline Body image & & $\begin{array}{l}0.23 \\
(0.001)^{* *}\end{array}$ & $\begin{array}{l}0.22 \\
(0.002)^{* *}\end{array}$ \\
\hline Self-esteem & $\begin{array}{l}0.23 \\
(0.001)^{* *}\end{array}$ & $\begin{array}{l}0.19 \\
(0.00)^{* *}\end{array}$ \\
\hline Quality of sexual life & 0.22 & $\begin{array}{l}0.19 \\
(0.00)^{* *}\end{array}$ & \\
\hline
\end{tabular}

\section{DISCUSSION:}

Undergo hysterectomy is a difficult process for every woman, especially psychologically. Uterus is the symbol of femininity, sexuality, fertility, and maternity, and the loss of this organ is identified as the loss of womanhood.

Scarring following hysterectomy can be interpreted as a form of mutilation and may result in impaired body image (Flory, et al, 2005). Thoughts like being scared of growing old, body image changes, and the sense of reduction in feminine properties after hysterectomy causes a self-esteem reduction, also may cause a sense of emptiness and a loss of creativity (Gün \& Kömürcü, 2013; Azadeh-et al,_2002). On the other hand, sexual functioning following hysterectomy is a major concern of patients.

The present study was conducted to assess the effect of hysterectomy on the body image, self-esteem, and quality of sexual life.

This study revealed that the highest percentages of women were highly concerned with their body image, while moderate percentage of women were moderately concerned and finally low percentage of women were low concerned with their body image. This is may be due to the old age of the majority of the women (between 55 to 65 years) while, the women aged between 25-35 years were highly concerned with their body image. This study agrees with Mokate, et al,_(2006) who conducted on 90 women in United States America to evaluate the outcomes of hysterectomy and found that women in abdominal hysterectomy group were low concern with their body image because of their abdominal scar compared to women in the vaginal hysterectomy group. This study result of this 
research was similar to the study of Pinar, et al, (2012) who investigate the differences in the effect of hysterectomy on body image, self-esteem, and marital adjustment in Turkish women with gynecologic cancer based on specific independent variables, including age, education, employment, having or not having children that show negative effects on body image, self-esteem, and dyadic adjustment in women. However this result was disagree with the study of Kuppermann et al., (2005) who investigate the hysterectomy outcomes, and found an improvement in health-related quality of life in particular body image during two years of follow-up. Also, in United States in a study of on 400 women who had undergone hysterectomy, indicated that self and body image remain consistent and only $25.3 \%$ indicating a change for the worse (Roussis, et al., 2004). Hysterectomies can negatively effects on the body image and many women have fears that they will lose their sexual attractiveness after hysterectomy, and they had avoided people very much because of the way they felt about the appearance. In addition, many women have complicated feelings after hysterectomy, about being moderately dissatisfied with the body.

One of the striking results of current study was that, women who undergo hysterectomy had higher self-esteem. It was found that most of cases reported that they took a positive attitude toward self and they had the ability to do things as well as most other people. In addition, they didn't feel useless at times after hysterectomy. Satisfying with the self on the whole and having number of good qualities. In the same manner, in turkey Eken et al., (2016) investigated the impact of laparoscopic and abdominal hysterectomy on quality of life, sexual function, and self-esteem, they found a postoperatively amelioration of self-respect which may be a substantial factor affecting sexual improvement. Also, in the research of Cohen, et al., (2011) in the South Central United States to study the influence of hysterectomy on self-esteem over the year after surgery they found that women had high self-esteem which did not significantly change overtime post hysterectomy. In contrast, studies to investigate psychological adjustment to operation, and to explore social, psychological and physical factors associated with psychological includes depression, anxiety, lowered self-esteem and altered sexual functioning (Margaret, et al., 2018).The findings indicated a high prevalence of preoperative psychological morbidity (55\%), hysterectomy has been associated with enervation of the vagina and surrounding tissues (i.e., perineum) due to dissection of the pelvic connective tissue that may change bladder sensations. Loss of control over body functions (bowel and urinary) concurrently with sexual morbidity may resulted in major 
psychological distress and threaten self-esteem, feelings of intimacy, identity, and relationships (Brotto et al., 2008).The present study also displayed that post hysterectomy women do have sexual satisfaction problems. Most of participated women reported that they felt something missing from their sexual life and there was not enough emotional closeness in their sexuality after hysterectomy. In addition, many women felt that her partner and she might not be physically attracted to each other enough after hysterectomy and she was very worry that her partner may have another partner because of her sexual difficulties and there no balance between that she give and receive in sex. Our findings is supported by Tozo et al., (2009) who suggested that hysterectomy has a negative influence on sexual life, with reports of reduced arousal, libido and orgasmic capacity. Also, LonnéeHoffmann \&Pinas, (2014) in United States and study effects of hysterectomy on sexual function and found that hysterectomy can result in impaired sexual function and raised long-term health risks. The deficiency androgen and oestrogen caused more aggravated climacteric symptoms and sexual dysfunctions such as decrease in sexual pleasure, frequency and comfort. However, our findings were contradicted with some studies which indicated that after hysterectomy there was no difference in the intercourse frequency, sexual drive, and orgasm in women Dragisic et al (2014). Moreover, in the study of Briedite, Ancane, Rogovska \& Lietuviete (2014) to assess and compare pre- and posthysterectomy quality of sexual life, they found that there were no statistically significant changes of sexual quality of life found after hysterectomy surgery. Furthermore, in a Netherlands study to investigate the effect of different hysterectomy types (vaginal, total abdominal and subtotal abdominal hysterectomy) on sexual wellbeing, it was reported that there was a significant improvement in women's sexual functions after the surgery (Roovers, van der Bom, van der Vaart \& Heintz, 2003). Also, in the German study of Gutl, Greimel, Roth \& Winter, (2002), they reported that there was a significant improvement in women's sexual behavior and activity after hysterectomy. Moreover, Kuppermann et al., (2005) study the sexual functioning after abdominal hysterectomy among 135 women in United States, they found that sexual problems improved dramatically during the first six months and stabilized by one year. These improvements are dependent on the level of sexual dysfunction before surgery and are higher in individuals who had more severe problems preoperatively. Furthermore, our results were in contrast to Merighi, et al. (2012) who found that hysterectomy was a factor improving the relationships including the sexual life. As derived from the present study, we found a positive correlation between patient's body image perceptions and their self-esteem $(r=0.23, P=0.001)$. In the same manner, there 
is a complex relationship between body image and self-esteem. In some women, low selfesteem stems from a negative body image, and can resulted into a negative body image in others (Yaman \& Ayaz, 2015).Women after hysterectomy reported that they avoidance of people because of the way women felt about appearance and in same manner have ability to do things as well as most other people. Also, (Kékes Szabó, 2015) reported that body image is one of the significant components of the individual's self-concept that provides the opportunity to reach a more healthy physical and mental state. The perception of the body and those feelings, which are associated with this image greatly influence not only self-concept, but also self-esteem. Furthermore, in many cases, distortions of visual perception were explored by individuals with negative body image (Kékes Szabó, 2015). Also, the present results found that there was a correlation between the patient's self-esteem and quality of their sexual life $(\mathrm{r}=0.19, \mathrm{P}=0.00)$. Women's have proud of to himself see sexual difficulties not affect her well-being. In the same manner, Ramezani, Dolatian, Shams \& Alavi, (2011) found that, in women, there was a significant correlation between sexual dysfunction and satisfaction and self-esteem in particular in those with low selfesteem that presented increased sexual dysfunction and satisfaction.

\section{CONCLUSION:-}

There was a strong positive correlation between the patient's body image and their selfesteem as well as quality of sexual life. Also, there was a positive correlation between the patient's self-esteem and quality of their sexual life.

\section{RECOMMENDATIONS:}

1) Hysterectomy results in prevention of pregnancy, which is a major and intolerable problem for women especially in young age, thus providing holistic preventive measures for high risk groups is recommended. Moreover, designing preventive programs for women in different health sectors entitled causes, risk factors, warning signs, various modalities and treatment as well as referrals is also suggested.

2) Provide comprehensive care plan in dealing with women undergoing hysterectomy.

Nurses should emphasize on the psychological status of women, thus they should provide continuous support and assistance in order to help women accept hysterectomy as a part of cancer_management. 


\section{REFERENCES:}

Afshari P., Houshyar Z., Javadifar N., Pourmotahari F., \& Jorfi M. (2016). The Relationship between Body Image and Sexual Function in Middle-Aged Women. Electronic physician, 8: 3302-8.

Azadeh-Ghamsari A., Gill R., Moerdyk N., Oberleitner B.\& Rademeyer K.(2002).The sexual and psychological implication of hysterectomy.South African medical journal,92:517-8.

Briedite I., Ancane G., Rogovska I., \& Lietuviete N. (2014). Quality of Female Sexual Function After Conventional Abdominal Hysterectomy-Three Month' Observation. Acta Chirurgica Latviensis, 14: 26-31.

Brotto L., Heiman J., Goff B., Greer B., Lentz G., Swisher E., Tamimi H. \& Van Blaricom A. (2008). A psychoeducational intervention for sexual dysfunction in women with gynecologic cancer. Arch Sex Behav, 37: 317-29.

Cohen S., Linenberger H., Wehry L. \& Welz H. (2011). Recovery after Hysterectomy. webmed central research article ,2046-1690.

Danesh M., Hamzehgardeshi Z., Moosazadeh M. \& Shabani-Asrami F. (2015). The Effect of Hysterectomy on Women's Sexual Function: a Narrative Review. Medical archives (Sarajevo, Bosnia and Herzegovina), 69: 387-92.

Dragisic K. \& Milad M. (2004).Sexual functioning and patient expectations of sexual functioning after hysterectomy. American journal of obstetrics and gynecology, 190: 14168.

Eken M., İlhan G. Temizkan O., Çelik E., Herkiloğlu D. \& Karateke A. (2016). The impact of abdominal and laparoscopic hysterectomies on women's sexuality and psychological condition. Turkish journal of obstetrics and gynecology, 13: 196-202.

Flory N., Bissonnette F., \& Binik Y. (2005). Psychosocial effects of hysterectomy: literature review. Journal of psychosomatic research, 59: 117-29.

Gamal S. (2015).body image, self -esteem and quality of sexual life after mastectomy. Mansoura nursing journal 2. 
Gün C. \& Kömürcü N. (2013). The relationship between self-esteem and self-care agency in hysterectomy patients. Journal of Research in Nursing and Midwifery, 2: 89-95.

Gutl P., Greimel E., Roth R. \& Winter R. (2002). Women's sexual behavior, body image and satisfaction with surgical outcomes after hysterectomy: a comparison of vaginal and abdominal surgery. Journal of psychosomatic obstetrics and gynecology, 23: 51-9

Hammer A., Rositch A., Kahlert J., Gravitt P., Blaakaer J. \& Sogaard M. (2015). Global epidemiology of hysterectomy: possible impact on gynecological cancer rates. American journal of obstetrics and gynecology, 213: 23-9.

Hopwood P,. (1993). The Assessment of Body image in cancer patient. Europen Journal of cancer 2 (276-281).

Illiano E., Giannitsas K. \& Costantini E. (2016). Hysterectomy and Sexuality. Int Urogynecol Journal, (10):1563-9.

Kékes Szabó M. (2015).The relation between body image and self-esteem .European psychiatry, 30:1354.

Kuppermann M., Summitt J., Varner R., McNeeley S., Goodman-G., Learman L., Ireland C., Vittinghoff E., Richter H., Showstack J., Hulley S.\& Washington A. (2005). Sexual functioning after total compared with supra cervical hysterectomy: a randomized trial. Obstetrics and gynecology, 105: 1309-18.

Lonnée-Hoffmann R. \& Pinas I. (2014). Effects of hysterectomy on sexual function. Current sexual health reports, 6: 244-51.

Margaret M., Lorraine D.\& Roger P. (2018).Psychological aspect of hysterectomy :A prospective study . The British journal of psychiatry,4: 516-522.

Merighi M., Oliveira D., Jesus M., Hoga K., \& Pedroso A. (2012). Experiências e expectativas de mulheres submetidas à histerectomia. Texto \& Contexto - Enfermagem, 21: 608-15.

Mokate T., Wright C., \& Mander T. (2006). Hysterectomy and sexual function. British Menopause Society Journal, 12: 153-7. 
Pinar G., Okdem S., Dogan N., Buyukgonenc L., \& Ayhan A. (2012). The effects of hysterectomy on body image, self-esteem, and marital adjustment in Turkish women with gynecologic cancer. Clinical Journal of Oncology Nursing, 16: 99-104.

Ramezani M., Dolatian M., Shams J. \& Alavi H. (2011). The relationship between selfesteem and sexual dysfunction and satisfaction in women. Obstetrics and gynecology journal,6:1209-1318

Roovers J., van der Bom J., van der Vaart C. \& Heintz A. (2003). Hysterectomy and sexual wellbeing: prospective observational study of vaginal hysterectomy, subtotal abdominal hysterectomy, and total abdominal hysterectomy. BMJ (Clinical research ed), 327: $774-8$.

Roussis N., Waltrous L., Kerr A., Robertazzi R., \& Cabbad M. (2004). Sexual response in the patient after hysterectomy: total abdominal versus supra cervical versus vaginal procedure. American journal of obstetrics and gynecology, 190: 1427-8.

Solbraekke K., Bondevik H., (2015). Absent organs-Present selves: Exploring embodiment and gender identity in young Norwegian women's accounts of hysterectomy, International Journal of Qualitative Studies in Health and Well-being, 10:10-3402.

Tozo I., Moraes J., Lima S., Gonçalves N., Auge A., Rossi L. \& Aoki T. (2009). Sexuality evaluation in women submitted to hysterectomy for the treatment of uterine leiomyoma. Revista brasileira de ginecologia e obstetricia: revista da Federacao Brasileira das Sociedades de Ginecologia e Obstetricia, 31: 503-7.

Yen J., Chen Y., Long C., Chang Y., Yen C., Chen C., \& Ko C. (2008). Risk factors for major depressive disorder and the psychological impact of hysterectomy: a prospective investigation. Psychosomatics, 49: 137-42. 


\section{الخــلاصــة}

الـمقدمة: استئصسال الرحم هو نوع من العمليات الجراحية، والتي يمكن أن تؤثر على حياة المريض. في الحقيقة أن

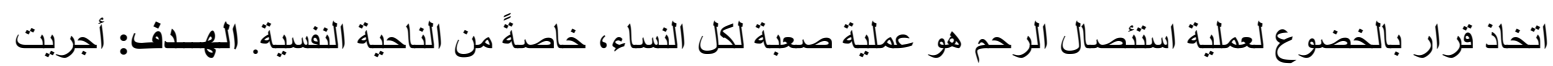

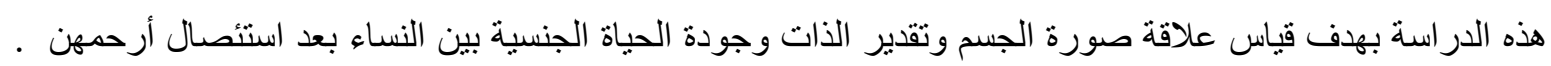
ادوات وطرق البحث: تم استخدام التصميم الوصفي البحثي الارتباطي. كانت الدر اسة تجري في العيادة الخارجية لمركز الأور ام في جامعة المنصورة. وشملت الدر اسة 188امر أة قمن بإجر اء عملية استنـصال للرحم. وقد تم استخدام ثلاثة أدوات لجمع البيانات، مقياس صورة الجسم، مقياس تقدير الذات واستبيان جودة الحياة الجنسية وبالإضافة لاستمارة البيانات

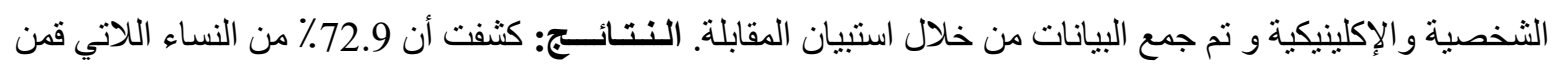
بإجر اء عملية استئصسال للرحم كانت مهتمة بصورة أجسامهن، 70.2٪ من النساء الاتي قمن بإجر اء عملية استئصال للرحم كان لديهن مستوى عالي من تقدير الذات، وذكرت أن 89.6٪ من النساء كانت راضيات عن حياتهن الجنسية بعد استئصال الرحم. الاستنتاجات: كان هناك ارتباط إيجابي قوي بين صورة جسم المريض وتقدير الذات أيضا علئ علاقة إيجابية بين السيدات وجودة حياتهن الجنسية. التوصيات في ضوء الاراسة الحالية: ينبغي عمل بر امج تعليمية صحية شاملة وكذلك بر امج إعادة التأهيل لجميع النساء بعد علاج السرطان في العيادات الخارجية لوحدات قسم الأورام ، بما في ذلك القضايا النفسية و الاجتماعية و الجسدية ذات 